\title{
Hunters' landscape accessibility and daily activity of ungulates in Yasuní Biosphere Reserve, Ecuador
}

\author{
Santiago Espinosa ${ }^{1,2^{*}}$ and Julia Salvador ${ }^{2}$ \\ ${ }^{1}$ Facultad de Ciencias, Universidad Autónoma de San Luis Potosí, Av. Salvador Nava Martínez s/n, Zona Universitaria, CP. 78290, \\ San Luis Potosí. San Luis Potosí, México. Email: santiago.espinosa@uaslp.mx (SE). \\ ${ }^{2}$ Escuela de Ciencias Biológicas, Pontificia Universidad Católica del Ecuador, Av. 12 de Octubre 1076 y Roca, Apartado 17-01-2184. \\ Quito, Ecuador. Email: julysalvador@hotmail.com (JS). \\ * Corresponding author
}

Ungulates are one of the most important groups in terrestrial ecosystems across the tropics. Also, ungulates are an important source of protein for people who inhabit tropical forests, and numerous studies have been conducted to evaluate the impact of hunting on the size of ungulate populations. However, little is known about other potential effects of hunting on these species. This study aims to analyze the effect of landscape accessibility to hunters on the daily activities of ungulates in Yasuní Biosphere Reserve, a protected area located in the Amazon region of Ecuador. We compared activity patterns (i. e., distribution of hours of activity along the day) and activity levels (i. e., proportion of hours of the day that an animal is active) for five ungulate species (white-lipped peccary Tayassu pecari, collared peccary Pecari tajacu, red brocket deer Mazama americana, brown brocket deer M. nemorivaga, and tapir Tapirus terrestris) in four sites differing in the degree of access to hunters. To this end, in each of the four study areas, a grid of camera traps was placed within a polygon of approximately $100 \mathrm{~km}^{2}$; traps operated continuously for three to four consecutive months. We recorded the date and time of detection for each species. Daily activity patterns and activity levels were estimated with kernel density analysis for circular data. Our work included a total of 9,506 effective trapping days for the four study sites, resulting in 1,063 separate records of the five ungulate species. In the four study areas, the brown brocket deer and the two species of peccaries concentrated their activity in daytime hours. The red brocket deer was most active in twilight hours, and the tapir was primarily nocturnal. At sites most accessible to hunters, the activity patterns of the collared peccary included a higher proportion of nighttime hours. The red brocket deer also seemed to increase the proportion of nighttime hours of its daily activity. The overall daily activity level was higher in the site with higher accessibility, but was statistically significant only for the collared peccary and the red brocket deer. Our findings include moderate statistically significant evidence suggesting that the access of hunters to the landscape influences the daily activity of ungulates in Yasuní. One species that is clearly affected by the access of hunters is the collared peccary, which becomes more nocturnal and increases its nighttime hours of activity when accessibility to hunters is higher. When our results are compared with other studies, it is evident that the species may display different behavioral responses to hunting, and that these responses may vary with the scale of analysis. This study was limited by sample sizes, which did not allow performing comprehensive analyses for all five species. To further understand the effects of hunting and other human activities on animal behavior, additional studies specifically designed for this purpose should be conducted.

Los ungulados constituyen uno de los grupos de mayor importancia en los ecosistemas terrestres de los trópicos. Adicionalmente, los ungulados son una fuente importante de proteína para los habitantes de los bosques tropicales y existen algunos estudios que evalúan el impacto de la cacería en el tamaño de las poblaciones de estas especies. Sin embargo, se conoce poco sobre otros efectos que la cacería puede tener en los ungulados. El propósito de este estudio fue evaluar el efecto de la accesibilidad de cazadores al paisaje en la actividad diaria de los ungulados en la Reserva de Biosfera Yasuní, un área natural protegida localizada en la región amazónica de Ecuador. Se comparó los patrones de actividad (i. e., distribución de horas de actividad en el día) y niveles de actividad (i. e., proporción de horas del día que un animal está activo) de cinco especies de ungulados (pecarí de labios blancos Tayassu pecari, pecarí de collar Pecari tajacu, venado colorado Mazama americana, venado marrón Mazama nemorivaga y tapir Tapirus terrestris) en cuatro sitios con diferente grado de accesibilidad de cazadores al paisaje. Para este propósito, en cada sitio se estableció una grilla de cámaras trampa en un polígono de aproximadamente 100 km², y que funcionó continuamente de tres a cuatro meses consecutivos. Para cada especie se registró su fecha y hora de detección. Los patrones y niveles de actividad diaria se estimaron por medio de un análisis de densidad de kernel para datos circulares. El esfuerzo total del presente trabajo fue de 9,506 días efectivos de muestreo entre los cuatro sitios de estudio que resultó en 1,063 registros independientes de las cinco especies de ungulados. En los cuatro sitios estudiados, el venado marrón y ambas especies de pecarí concentraron su actividad en la mañana. El venado colorado fue más activo en los crepúsculos y el tapir fue principalmente nocturno. En los sitios con mayor acceso de cazadores, el patrón de actividad del pecarí de collar incluyó una mayor proporción de horas de la noche. El venado colorado también pareció incrementar la proporción de horas nocturnas en su actividad diaria. En general, el nivel de actividad diaria fue más alto en el sitio de mayor acceso aunque estadísticamente significativo únicamente para el pecarí de collar y el venado colorado. Nuestro estudio encuentra pocas evidencias estadísticamente significativas de que la accesibilidad de cazadores al paisaje tiene un efecto en la actividad diaria de los ungulados en Yasuní. Una especie que muestra efectos claros es el pecarí de collar, que incrementa sus horas de actividad cuando la accesibilidad de cazadores al paisaje aumenta. Por medio de comparar nuestros resultados con otros estudios, observamos que la cacería puede tener efectos diferentes en el comportamiento de las especies, y que además, estos resultados pueden variar según la escala de análisis. Es importante notar que este estudio estuvo limitado por los tamaños de muestra que no permitieron realizar los mismos análisis para todas las especies. Para conocer a más profundidad los efectos de la cacería y otras actividades humanas en el comportamiento animal, sugerimos realizar más estudios específicamente diseñados para este propósito.

Key words: activity level; activity pattern; circadian activity; kernel analyses; Mazama americana; Mazama nemorivaga; Pecari tajacu; Tapirus terrestris; Tayassu pecari.

๑) 2017 Asociación Mexicana de Mastozoología, www.mastozoologiamexicana.org 


\section{Introduction}

Ungulates include the most hunted wild life species by local inhabitants in tropical ecosystems (Robinson and Bennett 2000; Jerozolimski and Peres 2003; Milner-Gulland et al. 2003). In the Neotropics, the study of the impact of hunting on this group of animals has focused on the assessment of their populations, since the decrease in the number of individuals is a serious threat for exploited populations (e. g., Peres 1996; Bodmer et al. 1997; Hurtado-Gonzales and Bodmer 2004; Reyna-Hurtado and Tanner 2007). However, other aspects of the exploited species, including their behavior, are still little known. In animal behavior, daily activity is a key element which, for instance, has been used to explain the sympatry of close species that share similar trophic niches, or the relationships between predators and their prey (e. g., Rivero et al. 2005; Harmsen et al. 2011).

The daily activity of organisms can be influenced by both physiological and environmental factors (e. g., habitat availability, presence of predators), including human activities (Kitchen et al. 2000; Foster and Kreitzman 2005). In the Netropics, daily activity patterns of ungulates have been described in several works (e. g., Carrillo et al. 2002; Noss et al. 2003; Gómez et al. 2005; Rivero et al. 2005; Tobler et al. 2009; Oliveira-Santos et al. 2010; Harmsen et al. 2011; Blake et al. 2012); however, the effect of human actions in this aspect of animal behavior has been little studied (e. g., Di Bitetti et al. 2008). Previous studies indicate that hunting affects the daily activity of wild pigs Sus scrofa in Germany (Keuling et al. 2008). On the other hand, in Argentina it has been observed that the red brocket deer Mazama americana increases its peaks of activity in the nighttime hours in areas with higher hunting levels, probably to evade hunters (Di Bitetti et al. 2008).

The aim of this work was to evaluate the effect of accessibility of hunters to the landscape on the daily activity of ungulates in Yasuní Biosphere Reserve, located in the Ecuadorian Amazon where there are five sympatric species of ungulates (white-lipped peccary Tayassu pecari, collared peccary Pecari tajacu, red brocket deer Mazama americana, brown brocket deer M. nemorivaga, and tapir Tapirus terrestris). To this end, this study analyses the daily activity in four sites that differ in the degree of accessibility to hunters. In addition, the results of this work are compared with a similar work conducted at a finer spatial scale in one of the sites included in this study (Salvador 2015). Because of its size, Yasuní is the protected area with the greatest potential for the conservation of viable ungulate populations in Ecuador. In Yasuní, however, ungulates are heavily exploited by indigenous hunters or settlers who live within or around the protected area and that use bushmeat as the main protein source or as an economic resource through bushmeat trade (Suárez et al. 2009; Espinosa et al. 2014). Our expectation is that a deeper knowledge of the relationships between human activities, such as hunting, and aspects of animal behavior, including activity patterns and levels, will contribute to the management and conservation of the species studied.

\section{Materials and Methods}

Study area. Yasuní Biosphere Reserve (YBR), Ecuador, is formed by Yasuní National Park $(1,000,000$ ha) and the Waorani Ethnic Reserve $(800,000$ ha; Figure 1). In addition, YBR consists of a buffer area that includes a $10 \mathrm{~km}$-wide strip around its northern, southern and western borders. Yasuní is a tropical rainforest ecosystem, with a mean annual precipitation of 3,000 $\mathrm{mm}$ and virtually no seasonality; there are no months with precipitation below $130 \mathrm{~mm}$ (Valencia et al. 2004).

Yasuní is inhabited mainly by indigenous groups that practice subsistence hunting. In the case of the Waorani (the main indigenous group that lives in Yasuní), hunting is conducted mainly in daylight hours; only $1.2 \%$ of the hunting events take place after 16:00 hours (Lu 1999). The hunting sessions last an average of 8 hours, and hunters, mostly men, are usually accompanied by other men, their wives or children; hunting is practiced by solitary hunters $25 \%$ of the time (Lu 1999).

Sampling of animals. Ungulates were studied using camera traps in four sites with different degree of accessibility to hunters. A previous study in Yasuní shows that the most accessible sites (i. e., the sites closest to villages, roads or navigable rivers), are those most intensively exploited by local hunters (Espinosa et al. 2014). The study sites are visited almost exclusively by local hunters, because accessibility to outsiders is very limited. The sites studied, from lower to higher degree of accessibility, were Lorocachi, Tiputini, Keweriono and Vía Maxus (Figure 1).

Lorocachi is a Kichwa community of approximately 120 inhabitants, located at the southern border of Yasuní, on the banks of the Curaray river. A 300-men military base is adjacent to Lorocachi. Reaching Lorocachi requires to travel by air; hunters move across the area on foot or by canoe along the Curaray river. The Kichwa community meets its protein demand through fishing, poultry breeding, and hunting. Hunting is managed by means of no-hunting zones and harvest quotas for some species such as the paujil (Mitu salvini), the Amazonian tapir and the white-lipped peccary (Vallejo-Real 2007). Our study site was located 3 to $21 \mathrm{~km}$ away from the Lorocachi community. The Amazon hunters walk a maximum distance of 8 to $9 \mathrm{~km}$ from access sources, such as houses, roads or rivers (Peres and Lake 2003; Espinosa et al. 2014). We estimated that about 70 to $80 \%$ of our Lorocachi study area was not accessible to hunters. Hunting by military personnel is prohibited; the army gets supplies from the Ecuadorian Armed Forces.

The Tiputini site was located next to the Tiputini river, in the Yasuní northern border. It is a non-inhabited area that is visited occasionally by Waorani and Kichwa hunters from nearby communities (Figure 1). To reach this site, hunters must navigate along the Tiputini river for three to five hours in motorized canoes. 
The Keweriono site was located in the vicinity of the Waorani of Keweriono (about 60 inhabitants) and Apaika (10 inhabitants) communities, located along the Shiripuno river and within an area corresponding to Waorani Territory, at the Yasuní western end. Apaika and Keweriono are located at 15 and $25 \mathrm{~km}$ from a road (Vía Auca), respectively and can be reached either by canoe or on foot. Waorani hunters have access to the entire study area, which has been hunted mainly for subsistence purposes since the creation of the Keweriono community in 1989 (Lu 1999; MenaValenzuela et al. 2000).

The Vía Maxus site was located in the vicinity of a road built by the Maxus oil company in the early 1990s. The Waorani settlements of Guiyero, Tiwe, Ganketa and Timpoka are located in the vicinity of this site and are home to approximately 70 inhabitants. Although the number of inhabitants is small, hunting in this area has been intense, since the local inhabitants have used wildlife as a source of income, trading substantial quantities of bushmeat in the local markets (Espinosa et al. 2014).

The sampling of animals was designed for a study on the jaguar (Espinosa 2012); however, the data obtained for ungulates show no biases that preclude the present analysis; there is no reason to believe that cameras influence the hours when an animal is either active or inactive. In each site, a quadrant including 23 to 26 sampling stations was set (Figure 1), which operated continuously for three to four consecutive months. Each station comprised two Leaf
River $^{\mathrm{TM}} \mathrm{C} 1-\mathrm{BU}$ camera traps placed in front of one another and perpendicular to trails. The stations were separated by two to three $\mathrm{km}$ and covered a minimum convex polygon of approximately $100 \mathrm{~km}^{2}$ at each site (Table 1). Sampling was carried out in the months with lower precipitation between December 2007 and November 2009 (Table 1).

Analysis of activity patterns and levels. The activity of organisms is divided into two components: activity pattern and activity level. The activity pattern describes the distribution of the activity of an organism throughout the day (e. g., diurnal, nocturnal, cathemeral), and the activity level indicates the proportion of hours per day that an animal is active (e. g., 0.5 corresponds to 12 hours of activity; Ridout and Linkie 2009; Rowcliffe 2015). Activity patterns and levels were estimated based on the date and time recorded for each snapshot captured by camera traps. All the analyses in this study included only records where the period between detections was equal to or longer than one hour for a given species in a given station; these records were considered independent events (Di Bitetti et al. 2008).

Daily activity patterns were estimated using the kernel density method, which is ideal for circular data (Schmid and Schmidt 2006; Ridout and Linkie 2009), using the 'overlap' package for $\mathrm{R}$ (Meredith and Ridout 2014). For each species, we estimated the overall activity patterns, that is, pooling the data of the four study sites for each species. In addition, for the collared peccary and the red brocket deer, we estimated site-specific activity patterns, since these

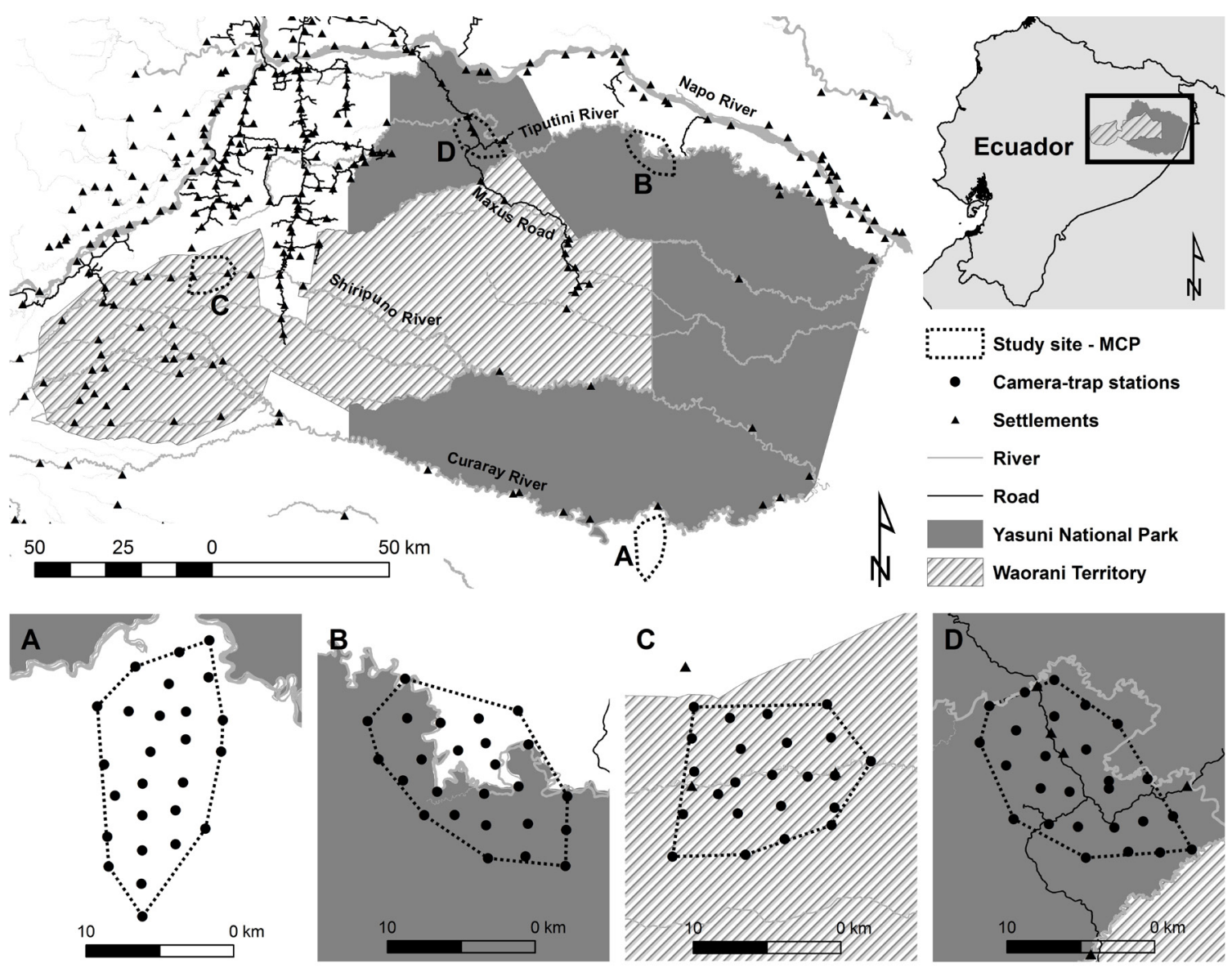

Figure 1. Study sites in the Yasuní Biosphere Reserve and its buffer zone. From lowest to highest accessibility to hunters: Lorocachi (A), Río Tiputini (B), Keweriono (C) and Vía Maxus (D). 
were the only species with sufficient data for analysis at this scale. To evaluate the effect of accessibility to the landscape on the activity patterns of these two species, the coefficients of overlap $\Delta$ were compared between the four study sites. The coefficients of overlap are defined as the proportion of the area under the curve that is superimposed between the two activity patterns, where $\Delta=0$ indicates no overlap (e. g., a strictly nocturnal organism compared with a strictly diurnal one), and $\Delta=1$ corresponds to a $100 \%$ overlap (i. e., both activity patterns are identical; Meredith and Ridout 2016). We would expect a greater overlap of activity patterns between sites with similar degrees of accessibility ( $i$. e., hunting), and a lesser overlap between sites with different degrees of accessibility. We used the $\Delta_{1}$ and $\Delta_{4}$ overlap estimates, which are suitable when one of the patterns to be compared comes from a sample smaller than or greater than 75 records, respectively (Ridout and Linkie 2009; Meredith and Ridout 2016). The $\Delta_{1}$ and $\Delta_{4}$ confidence intervals were estimated with a bootstrap method, using 10,000 random resampling of data with replacement (Meredith and Ridout 2014). The coefficients of overlap were estimated with the 'overlap' package for R (Meredith and Ridout 2014), and were compared by means of a probabilistic bootstrap test (1,000 resampling events) using the 'activity' package for R (compareCkern function; Rowcliffe 2015).

Daily activity levels were estimated with the fitact function in the 'activity' package for $\mathrm{R}$, which sets the hours, in radians, to a circular kernel density and estimates the activity level from this distribution (Rowcliffe 2015). For each of the five species recorded, daily activity levels were estimated both overall and for each particular site. For each of these estimates, we conducted a bootstrap with 1,000 resampling events; the statistical package provides measures of error (i. e., standard error and $95 \%$ confidence interval). To compare activity levels between sites, we used a Wald test run by the 'activity' package for $\mathrm{R}$ (compareAct function; Rowcliffe 2015).

\section{Results}

Data collection included 9,506 effective sampling days for the four study sites (Table 1 ). We obtained a total of 1,063 independent records of the five species of ungulates. Keweriono was the only site that did not record the five ungulate species present in Yasuní (Table 2).

Activity patterns and levels. The overall activity patterns and levels pool the data for each of the five species recorded in the four study sites. The white-lipped peccary, the collared peccary and the brown brocket deer showed a diurnal activity pattern, mostly between 06:00 h and 18:00 h (Figure 2). The red brocket deer showed two peaks of activity in the twilight, one at 06:00 $\mathrm{h}$ and the other at 18:00 $\mathrm{h}$. The Amazonian tapir was nocturnal and showed two peaks of activity, one between 20:00 to 22:00 and another between 03:00 to 04:00 h (Figure 2). The overall activity levels were $0.44(\mathrm{SE}=0.04)$ for the white-lipped peccary, 0.41 (SE = $0.02)$ for the collared peccary, $0.55(S E=0.05)$ for the red brocket deer, $0.43(\mathrm{SE}=0.05)$ for the brown brocket deer, and 0.52 ( $\mathrm{SE}=0.04)$ for the Amazonian tapir.

Effect of landscape accessibility of hunters on daily activity patterns. The distribution of the activity pattern of the collared peccary in Tiputini showed two diurnal peaks of activity, at 07:00 $\mathrm{h}$ and 12:00 h, while in the other three sites the activity pattern had a unimodal distribution (Figure 3 ). The differences between the activity patterns of the collared peccary were significant $(P=0.023)$ only between Lorocachi and Vía Maxus - the two sites with the lowest and highest degree of accessibility, respectively. When compared with Lorocachi, it is noted that in Vía Maxus the collared peccary decreases the diurnal and increases the nighttime activity (Figure 3 ).

The activity patterns of the red brocket deer were similar between the most and least accessible sites, and there
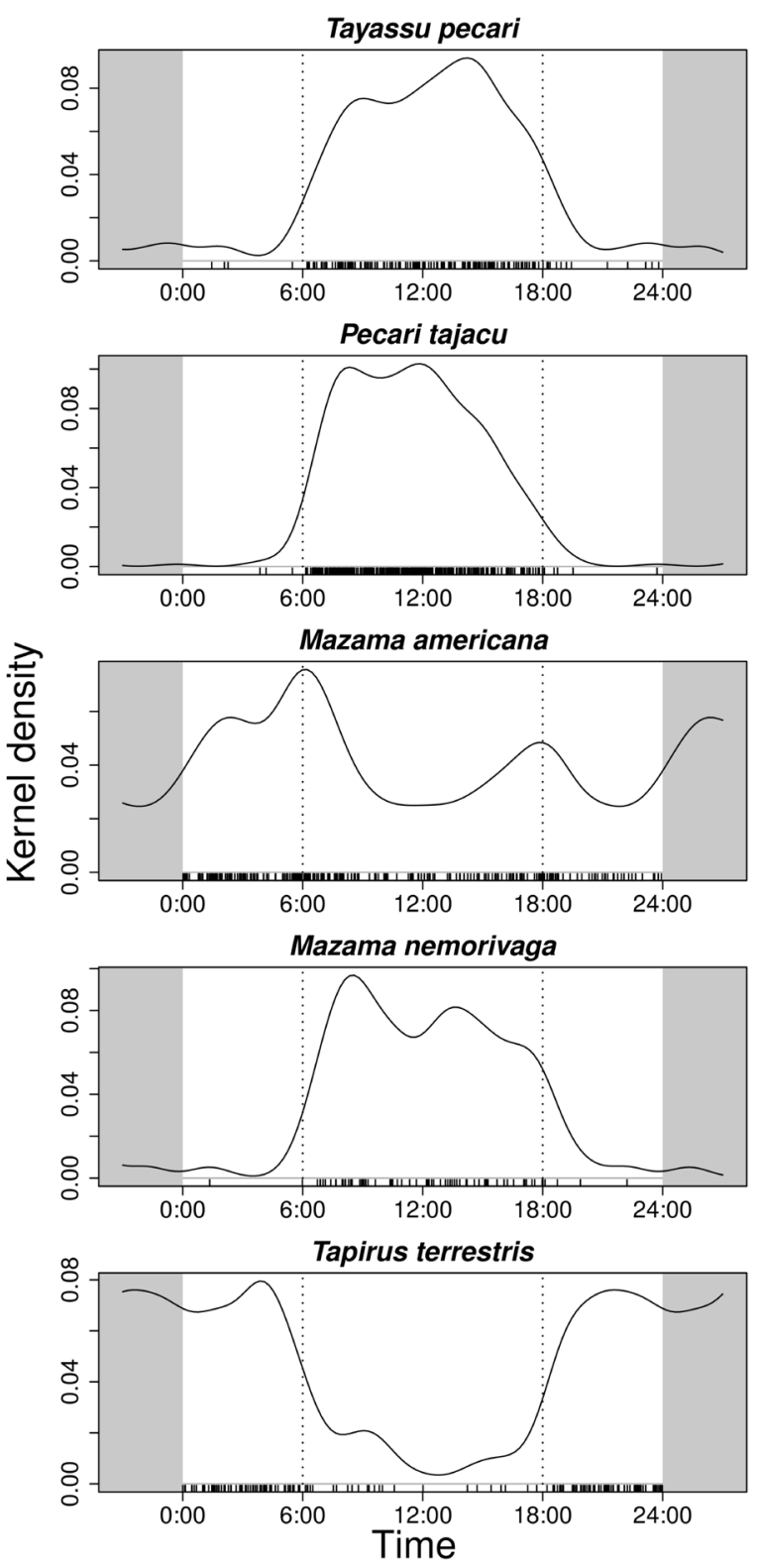

Figure 2. Overall activity patterns of ungulates in the Yasuní Biosphere Reserve. The strip at the base of the graphs represents the distribution of records for each species. The two parallel dotted lines represent approximate sunrise and sunset time in Ecuador, which vary approximately between $6: 00$ to $6: 30$ and $18: 00$ to $18: 30 \mathrm{~h}$, respectively, throughout the year. 
were no significant differences in the coefficients of overlap between sites (Figure 4). However, it was observed that in the two most accessible sites (Keweriono and Vía Maxus) the twilight activity of the red brocket deer increases around noon; in addition, in the latter site, the 18:00 $\mathrm{h}$ peak of activity shifted to approximately 19:00 to 20:00 h (Figure 4).

Effect of landscape accessibility of hunters on daily activity levels. In the ungulate species analyzed, except for the brown brocket deer, the daily activity level was highest in Vía Maxus, which is the most accessible site for hunters (Figure 5). However, these differences are statistically significant only in two cases and considering an $\alpha$ of $10 \%$ : the collared peccary between Lorocachi and Vía Maxus (Wald $\chi^{2}=2.85$, $\mathrm{d}$. $\left.\mathrm{f}_{\mathrm{f}}=1, P=0.091\right)$, and the red brocket deer between Tiputini and Vía Maxus (Wald $\chi^{2}=3.38$, d. f. $=1, P=0.066$; Table 3).

\section{Discussion}

The comparison of activity levels and patterns of species in sites with higher or lower accessibility levels by hunters showed few statistically significant differences, and these occurred in extreme cases. For instance, the activity pattern of the collared peccary was significantly different only between the most accessible site (Vía Maxus) and one of the two most remote sites (Lorocachi). Likewise, the activity level of the collared peccary was higher in Vía Maxus vs. Lorocachi, while the activity level of the red brocket deer was higher in Vía Maxus vs. Tiputini, the second most isolated site; these two results were significant at an a of $10 \%$. Therefore, it is evident that there are no solid results allowing to affirm that landscape accessibility by hunters affects the daily activity of organisms in general, although some species, such as the collared peccary, are seemingly affected by this factor.

To note, the changes in diurnal activity in the collared peccary and the red brocket deer showed an increase in nighttime activity in the most accessible sites. Similar patterns have been observed recently in a similar study in Vía
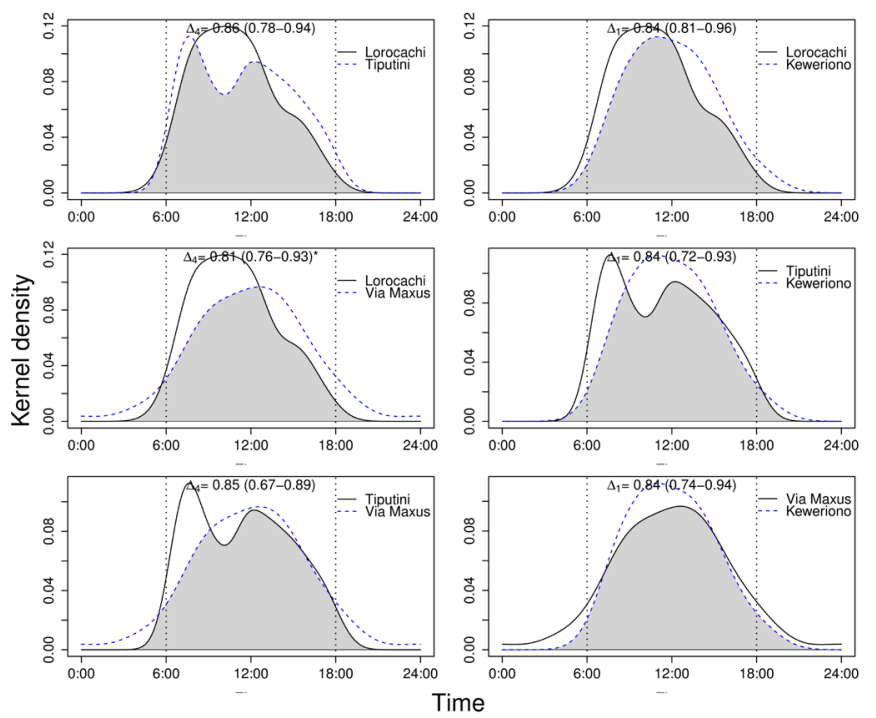

Figure 3. Overlap of the activity patterns of the collared peccary Pecari tajacu among the four study sites. The top of each chart details the coefficients of overlap, (95\% $\mathrm{Cl})$, for each comparison; *Significant difference ( $\alpha<5 \%)$.
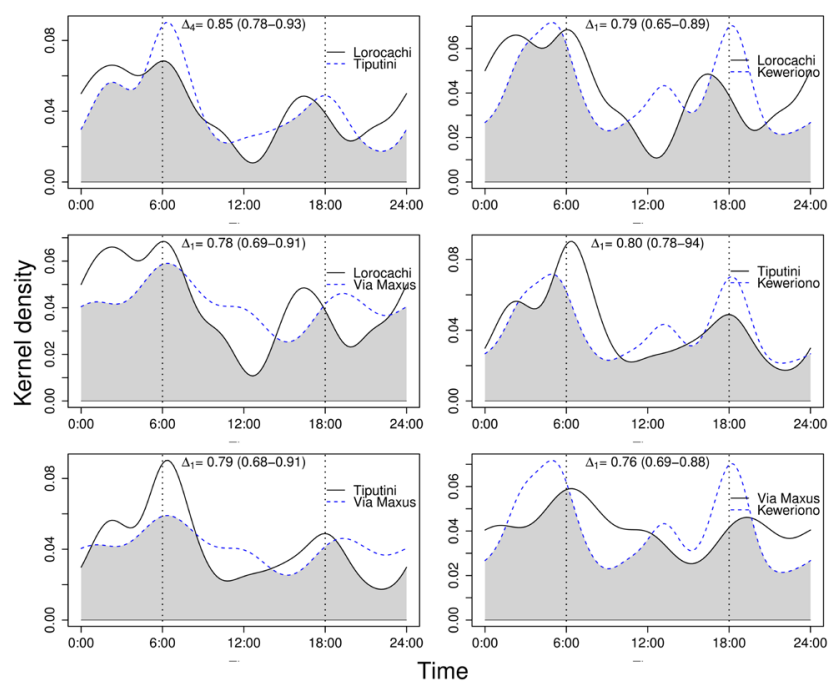

Figure 4. Overlap of the activity patterns of the red brocket deer Mazama americana among the four study sites. The top of each chart details the coefficients of overlap, $(95 \%$ $\mathrm{Cl}$ ), for each comparison; no case yielded significant differences between $\Delta$ estimates.

Maxus, where the red brocket deer increases the proportion of hours of nighttime activity (Salvador 2015) in sites that are close to human settlements (i. e., higher accessibility and hunting). The shift in the activity pattern toward nighttime in the presence of hunting has been observed previously in the red brocket deer, specifically in Argentina (Di Bitetti et al. 2008), as well as in other ungulate species, e. g., the Mediterranean mouflon Ovis gmelini musimon (Marchand et al. 2014), and the sika Cervus nippon (van Doormaal et al. 2015). These observations support that both the collared peccary and the red brocket deer display plasticity to adapt their activity pattern in response to human intervention, which partially explains their permanence in sites like Vía Maxus in Yasuní, where hunting is intense, although other factors such as source-sink dynamics may be more important (Espinosa et al. 2014).

Although there were virtually no significant differences, it is interesting to note a trend toward a higher activity level in the most accessible site (Vía Maxus) in four of the five species analyzed: tapir, white-lipped peccary, collared peccary

\begin{tabular}{lcccc}
\hline & Lorocachi & Tiputini & Keweriono & Vía Maxus \\
\hline $\begin{array}{l}\text { Camera trap } \\
\text { stations }\end{array}$ & 26 & 25 & 23 & 26 \\
$\begin{array}{l}\text { Installation of } \\
\text { the first camara } \\
\text { trap station }\end{array}$ & $07 / 11 / 2008$ & $11 / 20 / 2008$ & $08 / 05 / 2009$ & $11 / 24 / 2007$ \\
$\begin{array}{l}\text { Removal of the } \\
\text { last camara trap } \\
\text { station }\end{array}$ & $10 / 24 / 2008$ & $03 / 19 / 2009$ & $11 / 15 / 2009$ & $03 / 09 / 2008$ \\
$\begin{array}{l}\text { Effective trap- } \\
\text { days }\end{array}$ & 2458 & 2410 & 2132 & 2506 \\
$\begin{array}{l}\text { Minimum } \\
\text { convex polygon } \\
\text { of stations }\left(\mathrm{km}^{2}\right)\end{array}$ & 110 & 110 & 106 & 104 \\
\hline
\end{tabular}

Table 1. Sampling effort with camera traps in four sites across Yasuní Biosphere Reserve, Ecuador. The sites, ranked from lowest to highest accessibility to hunters, are: Lorocachi, Tiputini, Keweriono and Vía Maxus. 
Table 2. Ungulate species recorded by camera traps in four sites across Yasuní Biosphere Reserve, Ecuador. The sites, ranked from lowest to highest accessibility to hunters, are: Lorocachi, Tiputini, Keweriono and Vía Maxus.

\begin{tabular}{lccccc} 
& Lorocachi & Tiputini & Keweriono & $\begin{array}{c}\text { Vía } \\
\text { Maxus }\end{array}$ & Total \\
\hline Tapirus terrestris & 50 & 80 & 6 & 33 & 169 \\
Tayassu pecari & 21 & 152 & 0 & 7 & 180 \\
Pecari tajacu & 121 & 129 & 41 & 76 & 367 \\
Mazama americana & 99 & 105 & 40 & 27 & 271 \\
Mazama nemorivaga & 17 & 44 & 0 & 15 & 76 \\
\hline
\end{tabular}

and red brocket deer. This finding seemingly opposes what we might intuitively expect, because more active individuals would be more exposed to hunting. In a study at a finer scale in Vía Maxus, Salvador (2015) reports a higher activity level of the tapir in areas adjacent to Waorani settlements, similar to the observations in this study (i.e., higher activity levels in more accessible sites). However, Salvador (2015) also notes that the activity of the white-lipped peccary and the red brocket deer was significantly higher in sites further away from the road or Waorani settlements, which are visited less frequently by local hunters (Espinosa et al. 2014). These seemingly contradictory observations indicate differential responses of species to disturbance, and may vary according to the scale of analysis.

An explanation for the increase in activity of ungulates in places more accessible to hunters is that, in addition to the time required for foraging, individuals need to spend time escaping from hunters or moving to safer places. It is well known that ungulate populations subjected to hunting pressure display a higher escape response versus populations in areas with no hunting pressure (Stankowich 2008). For example, it has been documented that hunting and other human activities lead to an increase in the daily movement of the American bison Bison bison (Fortin and Andruskiw 2003), and an increase in the level of vigilance of the red deer Cervus elaphus (Jayakody et al. 2008) and the European roe deer Capreolus capreolus (Benhaiem et al. 2008). However, little is known about the escape responses of Neotropical ungulates to the various disturbances caused by human activities (e. g., hunting, presence of domestic animals, and recreational activities, among others).

Animals can respond to hunting in manners that resemble those observed in relation to their natural predators (Frid and Dill 2002). A common behavioral response of prey to the risk of predation is to avoid high-risk areas where predators or hunters are usually abundant. Therefore, human hunters can force prey to move to safer habitats, causing physiological stress, escape behaviors and alteration of the rhythms of activity (Frid and Dill 2002; Crosmary et al. 2012; Matassa and Trussell 2014). These behavioral responses have been reported in a number of organisms, ranging from aquatic birds (Fox and Madsen 1997) to large ungulates (Stankowich 2008). In the Neotropics, we have significant information related to the activity patterns of

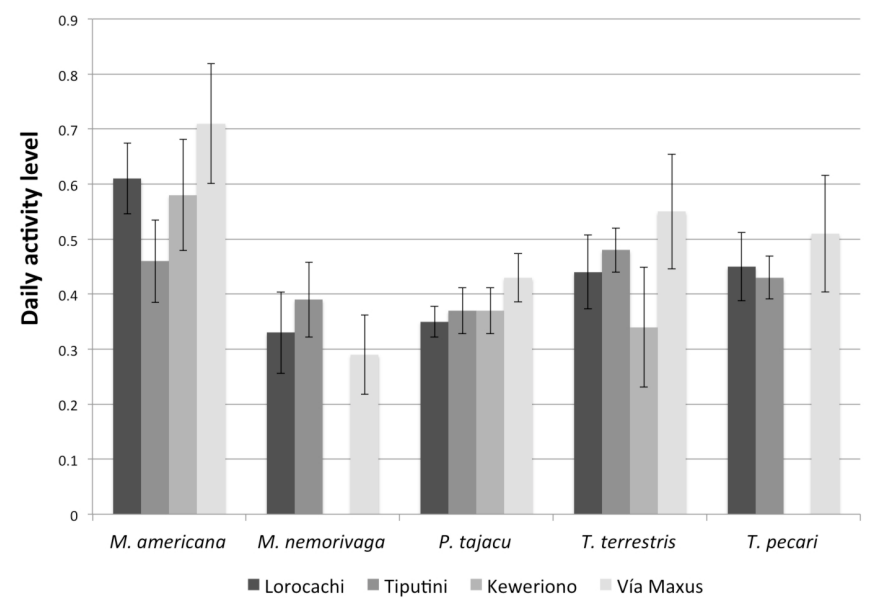

Figure 5. Daily activity level (i. e., proportion of hours per day that an animal is active) of ungulates across the four study sites in Yasuní; error bars represent the standard error.

ungulates (e. g., Carrillo et al. 2002; Noss et al. 2003; Gómez et al. 2005; Rivero et al. 2005; Tobler et al. 2009; OliveiraSantos et al. 2010; Harmsen et al. 2011; Blake et al. 2012). However, there are still scarce studies to better understand the effects of anthropic actions on the daily activity of these organisms.

Table 3. Absolute differences in the daily activity level (i. e., proportion of hours per day that an animal is active) of ungulates across the four study sites; standard errors are shown in parenthesis.

\begin{tabular}{|c|c|c|c|c|}
\hline & & Tiputini & Keweriono & Vía Maxus \\
\hline \multirow[t]{3}{*}{ Mazama americana } & Lorocachi & $\begin{array}{c}0.147 \\
(0.097)\end{array}$ & $\begin{array}{c}0.028 \\
(0.111)\end{array}$ & $\begin{array}{c}0.097 \\
(0.126)\end{array}$ \\
\hline & Tiputini & - & $\begin{array}{c}0.119 \\
(0.118)\end{array}$ & $\begin{array}{c}0.244 \\
(0.133)^{*}\end{array}$ \\
\hline & Keweriono & - & - & $\begin{array}{c}0.125 \\
(0.143)\end{array}$ \\
\hline \multirow[t]{3}{*}{ Mazama nemorivaga } & Lorocachi & $\begin{array}{c}0.063 \\
(0.100)\end{array}$ & NA & $\begin{array}{c}0.037 \\
(0.103)\end{array}$ \\
\hline & Tiputini & - & NA & $\begin{array}{c}0.100 \\
(0.099)\end{array}$ \\
\hline & Keweriono & - & - & NA \\
\hline \multirow[t]{3}{*}{ Pecari tajacu } & Lorocachi & $\begin{array}{c}0.022 \\
(0.049)\end{array}$ & $\begin{array}{c}0.023 \\
(0.052)\end{array}$ & $\begin{array}{c}0.083 \\
(0.049)^{*}\end{array}$ \\
\hline & Tiputini & - & $\begin{array}{c}0.002 \\
(0.060)\end{array}$ & $\begin{array}{c}0.061 \\
(0.056)\end{array}$ \\
\hline & Keweriono & - & - & $\begin{array}{c}0.060 \\
(0.059)\end{array}$ \\
\hline \multirow[t]{3}{*}{ Tapirus terrestris } & Lorocachi & $\begin{array}{c}0.043 \\
(0.078)\end{array}$ & $\begin{array}{c}0.091 \\
(0.128)\end{array}$ & $\begin{array}{c}0.116 \\
(0.124)\end{array}$ \\
\hline & Tiputini & - & $\begin{array}{c}0.132 \\
(0.116)\end{array}$ & $\begin{array}{c}0.075 \\
(0.112)\end{array}$ \\
\hline & Keweriono & - & - & $\begin{array}{c}0.207 \\
(0.151)\end{array}$ \\
\hline \multirow[t]{2}{*}{ Tayassu pecari } & Lorocachi & $\begin{array}{c}0.016 \\
(0.073)\end{array}$ & NA & $\begin{array}{c}0.062 \\
(0.122)\end{array}$ \\
\hline & Tiputini & - & NA & $\begin{array}{c}0.078 \\
(0.122)\end{array}$ \\
\hline
\end{tabular}

Keweriono

*Significant difference ( $\alpha<10 \%$ ); Not Available (NA): T. pecari and M. nemorivaga were not registered in Keweriono.. 
This study shows some evidence of the effects of the accessibility of hunters to the landscape on the daily activity of ungulates that inhabit Yasuní. However, further information is needed to draw clearer conclusions, since the limited data available did not allow to perform the same analysis for all the species studied. This lack of information for some species is linked to hunting, and demonstrates the negative effect of this activity on animal populations when management is inadequate (Reyna-Hurtado and Tanner 2007). For example, in Keweriono the white-lipped peccary, one of the species most heavily hunted by the Waorani, has not been observed over the past 20 to 30 years (Mena-Valenzuela et al. 2000, Espinosa et al. 2014).

The comparison of our results with those obtained in a separate study (Salvador 2015) revealed that in one of the sites included in this study (Vía Maxus) the type of behavioral response of ungulates to hunting may vary between species and may change according to the scale of analysis. The knowledge of the factors that influence animal behavior is relevant to understand how species adapt and persist in their habitats, thus making it necessary to evaluate the impacts of potential management alternatives, such as hunting or tourist activities. We believe it is necessary to expand the research with studies specifically designed to address questions related to animal behavior.

\section{Acknowledgments}

We are grateful to the University of Florida, WCS, WWF and Panthera for the funds provided to carry out this work. We also thank the Waorani and Kichwa communities that allowed us to work in their territories. This work would not have been possible without the logistical support of the Yasuní-PUCE Scientific Station, the Tiputini-USFQ Biodiversity Station, and the 48 Forest Battalion of the Armed Forces of Ecuador. Finally, we appreciate the comments of three anonymous reviewers who made a significant contribution to improve this manuscript. María Elena Sánchez-Salazar translated the manuscript into English.

\section{Literature cited}

Blake, J. G., D. Mosquera, B. Loiselle, K. Swing, J. Guerra, and D. Romo. 2012. Temporal activity patterns of terrestrial mammals in lowland rainforest of Eastern Ecuador. Ecotropica 18:137-146.

Benhaiem, S., M. Delon, B. Lourtet, B. Cargnelutti, S. Aulagnier, A. J. M. Hewison, N. Morellet, and H. Verheyden. 2008. Hunting increases vigilance levels in roe deer and modifies feeding site selection. Animal Behaviour 76:611-618.

Bodmer, R. E., J. F. EisenberG, and K. H. Redford. 1997. Hunting and the likelihood of extinction of Amazonian mammals. Conservation Biology 11:460-466.

Carrillo, E., J. C. Saenz, and T. K. Fuller. 2002. Movements and activities of white-lipped peccaries in Corcovado National Park, Costa Rica. Biological Conservation 108:317-324.

Crosmary, W.-G., M. Valeix, H. Fritz, H. Madzikanda, and S. D. Côté. 2012. African ungulates and their drinking problems: hunting and predation risks constrain access to water. Animal Behaviour 83:145-153.
Di Bitettı, M. S., A. Paviolo, C. A. Ferrari, C. De Angelo, and Y. Di BLANCO. 2008. Differential responses to hunting in two sympatric species of brocket deer (Mazama americana and M. nana). Biotropica 40:636-645.

EsPINOSA, S. 2012. Road development, bushmeat extraction and jaguar conservation in Yasuní Biosphere Reserve - Ecuador. Tesis de Doctorado. University of Florida. Gainesville, U. S. A. Espinosa, S., L. C. Branch, and R. Cueva. 2014. Road development and the geography of hunting by an Amazonian indigenous group: consequences for wildlife conservation. PLoS ONE 9(12):e114916. doi:10.1371/journal.pone.0114916

Fortin, D., And M. Andruskiw. 2003. Behavioral Response of Free-Ranging Bison to Human Disturbance. Wildlife Society Bulletin 31:804-813.

Foster, R. G., and L. Kreitzman. 2005. Rhythms of life: the biological clocks that control the daily lives of every living thing. Yale University Press. New Haven, U. S. A.

Fox, A. D., AND J. MAdSEN. 1997. Behavioural and distributional effects of hunting disturbance on waterbirds in Europe: implications for refuge design. Journal of Applied Ecology 34:1-13.

FrID, A., AND L. DILl. 2002. Human-caused disturbance stimuli as a form of predation risk. Conservation Ecology 6:11. URL: http://www.consecol.org/vol6/iss1/art11

Gómez, H., R. B. Wallace, G. Ayala, and R. Tejada. 2005. Dry season activity periods of some Amazonian mammals. Studies on Neotropical Fauna and Environment 40:91-95.

Harmsen, B. J., R. J. Fostera, S. C. Silver, L. E. T. Ostrod, and C. P. DONCASTER. 2011. Jaguar and puma activity patterns in relation to their main prey. Mammalian Biology 76:320-324.

Hurtado-Gonzales, J. L., And R. E. Bodmer. 2004. Assessing the sustainability of brocket deer hunting in the TamshiyacuTahuayo Communal Reserve, northeastern Peru. Biological Conservation 116:1-7.

Jayakody, S., A. M. SibBald, I. J. Gordon, and X. Lambin. 2008. Red deer Cervus elaphus vigilance behaviour differs with habitat and type of human disturbance. Wildlife Biology 14:81-91.

Jerozolimski, A., And C. A. Peres. 2003. Bringing home the biggest bacon: A cross-site analysis of the structure of hunter-kill profiles in Neotropical forests. Biological Conservation 111:415-425.

Keuling, O., N. Stier, and M. Roth. 2008. How does hunting influence activity and spatial usage in wild boar Sus scrofa L.? European Journal of Wildlife Research 54:729-737.

Kitchen, A. M., E. M. Gese, and E. R. Schauster. 2000. Changes in coyote activity patterns due to reduced exposure to human persecution. Canadian Journal of Zoology 78:853-857.

Lu, F. 1999. Changes in subsistence patterns and resource use of the Huaorani indians in the Ecuadorian Amazon. Tesis de Doctorado. University of North Carolina, Chapel Hill, NC.

Marchand, P., M. Garel, G. Bourgoin, D. Dubray, D. Maillard, and A. LOISON. 2014. Impacts of tourism and hunting on a large herbivore's spatio-temporal behavior in and around a French protected area. Biological Conservation 177:1-11.

Matassa, C. M., and G. C. Trussell. 2014. Prey state shapes the effects of temporal variation in predation risk. Proceedings of the Royal Society B 281:20141952.

Mena-Valenzuela, P., J. R. Stallings, J. Regalado, and R. Cueva. 2000. The sustainability of current hunting practices by the 
Huaorani. Pp. 57-78, in Hunting for sustainability in tropical forests (Robinson, J. G., and E. L. Bennett, eds.). Columbia University Press. New York, U. S. A.

Meredith, M., AND M. Ridout. 2014. overlap: Estimates of coefficient of overlapping for animal activity patterns $\mathrm{R}$ package version 0.2.3. Accesible en: https://cran.r-project.org

Meredith, M., And M. Ridout. 2016. Overview of the overlap package. Accesible en: https://cran.r-project.org

Milner-Gulland, E. J., E. L. Bennett, K. Abernethy, M. Bakarr, R. Bodmer, S. J. Brashares, G. Cowlishaw, P. Elkan, H. Eves, J. Fa, C. A. Peres, C. Roberts, J. Robinson, M. Rowcliffe, and D. Wilkie. 2003. Wild meat: The big picture. Trends in Ecology and Evolution 18:351-357.

Noss, A. J., R. L. Cuéllar, J. Barrientos, L. Maffel, E. Cuéllar, R. Arispe, D. Rúmiz, AND K. Rivero. 2003. A camera trapping and radio telemetry study of lowland tapir (Tapirus terrestris) in Bolivian dry forest. Tapir Conservation-Newsletter of the IUCN/SSC Tapir Specialist Group 12:24-32.

Oliveira-Santos, L. G. R., , L. C. P. Machado-Filho, M. A. Tortato, and L. Brusius. 2010. Influence of extrinsic variables on activity and habitat selection of lowland tapirs (Tapirus terrestris) in the coastal sand plain shrub, southern Brazil. Mammalian Biology 75:219-226.

Peres, C. A. 1996. Population status of the white-lipped Tayassu pecari and collared peccaries T. tajacu in hunted and unhunted Amazonian forests. Biological Conservation 77:115-123.

Peres, C. A., And I. R. Lake. 2003. Extent of nontimber resource extraction in tropical forests: accessibility to game vertebrates by hunters in the Amazon basin. Conservation Biology 17:521-535.

Reyna-Hurtado, R., and G. W. Tanner. 2007. Ungulate relative abundance in hunted and non-hunted sites in Calakmul Forest (Southern Mexico). Biodiversity and Conservation 16:743-756.

RIDOUT, M. S., AND M. LinKIE. 2009. Estimating overlap of daily activity patterns from camera trap data. Journal of Agricultural, Biological and Environmental Statistics 14:322-337.

Rivero, K., D. I. Rumiz, AND A. B. TABer. 2005. Differential habitat use by two sympatric brocket deer species (Mazama americana and M. gouazoubira) in a seasonal Chiquitano forest of Bolivia. Mammalia 69:169-183.

Robinson, J. G., AND E. L. BennetT. 2000. Carrying capacity limits to sustainable hunting in tropical forests. Pp. 13-30 in Hunting for sustainability in tropical forests (Robinson, J. G., and E. L. Bennett, eds.). Columbia University Press, New York.

Rowcliffe, M. 2015. R Package 'activity'. Accesible en: https:// cran.r-project.org

SCHMID, F., AND A. SCHMidT. 2006. Nonparametric estimation of the coefficient of overlapping - Theory and empirical application. Computational Statistics and Data Analysis 50:1583-1596.

SALVADOR, J. 2015. Effects of human disturbance on occurrence patterns and behavior of terrestrial mammals in eastern Ecuador. Tesis de Maestría. University of Florida. Gainesville, U. S. A.

StANKoWICH, T. 2008. Ungulate flight responses to human disturbance: a review and meta-analysis. Biological Conservation 141:2159-2173.

Suárez, E., M. Morales, R. Cueva, V. Utreras Buchel, G. Zapata-Ríos, E. Toral, J. Torres, W. Prado, and J. Vargas Olalla. 2009. Oil industry, wild meat trade and roads: indirect effects of oil extraction activities in a protected area in north-eastern Ecuador. Animal Conservation 12:364-373.

Tobler, M. W., S. E. Carrillo-Percastegul, and G. Powell. 2009. Habitat use, activity patterns and use of mineral licks by five species of ungulate in south-eastern Peru. Journal of Tropical Ecology 25:261-270.

Valencia, R., R. B. Foster, G. Villa, R. Condit, J. C. Svenning, C. Hernandez, K. Romoleroux, E. Losos, E. Magard, and H. Balslev. 2004. Tree species distributions and local habitat variation in the Amazon: large forest plot in eastern Ecuador. Journal of Ecology 92:214-229.

Vallejo-Real, I. 2007. Experiencias etnoambientales, etnozoneamiento y derechos territoriales en la amazonía centro. Pp. 507-541, in II Congreso Ecuatoriano de Antropología y Arqueolgía Tomo 2. (F. García, ed.). Ediciones Abya-Yala. Quito, Ecuador.

van Doormaal, N., H. Ohashi, S. Kolke, And K. KaJl. 2015. Influence of human activities on the activity patterns of Japanese sika deer (Cervus nippon) and wild boar (Sus scrofa) in Central Japan. European Journal of Wildlife Research 61:517-527.

Associated editor: Lia Méndez

Submitted: September 2, 2016; Reviewed: November 7, 2016;

Accepted: January 19, 2017; Published on line: January 25, 2017. 